\title{
ISSUES ON THE APPLICATION OF A QUALITY-RISK MANAGEMENT SYSTEM IN A HEALTHCARE SERVICES PROVIDER UNIT
}

\author{
CONSTANTIN MILITARU ${ }^{1}$, LEONARDO VOINESCU ${ }^{2 *}$ \\ ${ }^{1}$ University Politehnica of Bucharest, Romania \\ ${ }^{2}$ B.I.K.O, Fruhlingstr. 14c 90547 Stein, Germany
}

\begin{abstract}
A medical service, as a public service, is composed of a provider represented by the medical staff and a framework that carries out their work. Therefore, a qualitative management of services must be taken into account, on the one hand by the quality of care itself, and on the other hand by how the resource material is managed throughout the services provided. Fortunately, quality and risk management systems concepts are becoming ${ }^{1}$ more widely used in their speech, by the responsible with those services at European and national level. A quality medical service can be attained through a rigorous and effective management of the quality of medical care itself, and through increased quality of human resources and materials involved and ensuring health and reduce the risks of treatment/ care patients. The authors present in brief a model of risk assessments and risk classification in a medical unit.
\end{abstract}

Keywords: healthcare services, quality management system, risk management system, patient satisfaction

\section{CHARACTERISTICS OF THE CURRENT SITUATION AT EUROPEAN LEVEL}

The current economic context is marked by the increasing quality importance as a determinant for the competitiveness of organizations. More and more service provider organizations use techniques and instruments applied in quality management that are designed to facilitate continuous improvement of performance, to meet customer's needs in terms of efficiency and effectiveness [1].

On the other hand, risk management is not only a concern of the modern world. It has been here since the establishment of human communities, manifesting itself in various forms of conservation or confrontation, and has developed gradually up to risk treatment deliberate action, to prevent attacks or amend vulnerabilities. The business environment is influenced by risks, uncertainty and speed. Therefore, the best organizations do not take risk as a matter of compliance, but as an integral part of the decision-making process.

All the more, the specialists involved in the Technical Committees of the International Organization for Standardization (ISO) have introduced the concept that refers to risk since the 2008 edition of ISO 9001, and on the ongoing issue of ISO 9001 edition development, addressing risk in the process of quality improvement processes of an organization is essential.

\footnotetext{
*Corresponding author, email: lev.voinescu@gmail.com (C) 2015 Alma Mater Publishing House
} 
Health status has a complex content and is an inter-relationship with social evolution as a whole, with the other components of the economy and quality of life. This is determined by the overall level of economic and social development, by the consumption structure, by the individual hygiene standard, by the level of culture, and last but not least, by the healthcare services [2].

Quality management and risk management concepts are becoming widely used in speech-makers with effective exercise of medical activity, at European and national level. A quality medical service can be achieved both through a rigorous and effective management of the quality of medical care itself and through increased quality of human and material resources involved in ensuring the health and reduce the risks of treatment /under care patients.

An integrated management system is a logical and systematic management approach allowing optimal strategic and operational decisions that take into account all essential aspects leading to the efficient functioning of an organization, both in terms of quality and safety and on the environment or food hygiene or risk, etc.

In services management, especially those dedicated to people, quality is possible as a criterion of differentiating suppliers among them, and when it can step in concerning the mechanism of supply and demand of services. In conditions of free competition, quality is an important tool to mobilize human resources for finding boundaries separating quality from non-quality and over-quality, unwanted and costly extremes.

In the context of a single market at European level and in the context of liberalization of public services, including healthcare services, new providers of medical services were noticed and they became dominant on the market through an increased quality of the services provided. They will certainly have to meet certain criteria for a comparison to be made between them. On the other hand, the recipients of a service, the clients of an organization will have to have a way to distinguish what is good and what is not satisfactory, a way to be able to be oriented towards something that match their needs and why not, to meet their needs.

\section{CONCEPTUAL APPROACH: QUALITY OR RISK}

The quality of healthcare services, medical mistakes during practice and medical liability are topics that have been permanently placed at the forefront of attention of worldwide researchers. Recently, however, medical malpractice is under a special attention of the society, making the subject not only for medical journals but increasingly taking over the front page of the news, radio or television. Medical errors represent an almost unavoidable constant factor of medical practice as 12,483 cases were officially registered in Germany in 2012, ranging from treatment errors, incorrect operations to difficulties arising from childbirth [3].

The quality of healthcare services, the risks caused by the medical profession and medical liability are actual issues and are at the forefront of scientific research.

The health care system permanently registers not allowed losses that lead to high costs for the society. These losses arise from several causes [4]:

$>$ Bad or ineffective medical or healthcare technologies;

$>$ Big fluctuations of medical practice performance and of its results in various units providing healthcare services;

$>$ Unequal access to healthcare services;

$>$ Patient dissatisfaction with the services received and increasing of waiting time for receiving healthcare services; and so on.

Consequently, the quality of medical services becomes a priority for health care providers, managers, patients, paying third party, but also for the governmental institutions/organizations.

It is necessary to discuss the quality of medical services, because, in our days the state, the government, the ministries, must provide the framework for the suppliers of quality medical care. It is no longer enough for the state to provide for the right to health care, but it must provide quality medical care.

Moreover, providers, either private or public, must provide quality services in their turn. It is no longer a choice but an obligation. Suppliers are eager to demonstrate their competence in well-equipped hospitals. Patients are 
interested in receiving necessary care, with full respect for their rights as soon as possible from the provider they have chosen. The payers are interested to introduce quality standards, criteria and indicators in hospitals to efficiently manage costs. A traditional tool for quality improvement is questioning customers (patients, caregivers) to determine their level of satisfaction in relation to the objectives for present and future medical clinic. Handing questionnaires by medical personnel, especially by doctors, has a higher response rate to the questionnaires placing them in visible places, waiting room, etc. entering the offices [5].

That is the reason, why the subject of quality of health care is extremely controversial, with implications both at economic, financial, technological level and at human resources and organizational management level [4].

Medical services organizations are exposed at "classical" risk, the most common being the risk of accidental contamination of personnel as well as at derived "new risks", the most known and more difficult to manage being the allegations of malpractice and the existence of trade agreements between medical staff and third companies holding interests in the field, which may affect both the patient and the organization where the medical staff operates.

The quality of health services, mistakes in exercise of the medical profession and medical liability are subjects that always stood in the forefront of attention of researchers [6]. More recently, however, society are targeted on medical malpractice, making the subject of medical journals, articles in print and electronic media, radio and television reports, etc.

"Risk Dosage" is based on multiple factors, taking into account not only the expertise of doctors, against the progress registered by the medical science, the state of the art of a certain moment in time, but also the conditions under which medical care can be provided in the medical unit in question, the adequate medical equipment, the presence of other experts who could be required if some complications appear and the disease itself, the reactivity to the treatment of the patient or the ability to trigger intolerance reactions [7]. Also, medical risk assessment must be linked to the rights and obligations of the physician to the patient and to the medical establishment itself [7].

Risk management in medical services units has certain features depending on the sensitive area subjected to performance.

Risk managers in healthcare organizations work with a variety of functional areas: not only risk management, but also the quality of provided services (treatments, different medical services, hosting patients, etc.), patient safety, compliance with laws and medical guidelines, audit, and, not last but not least, insurance for the risk of malpractice [8]. These areas have a common denominator in terms of management and risk prevention ("bad" events, nonconformities in deploying the activities), but in most cases, they lack a common framework for risk management approach. In addition, risk management teams often complain about big difficulty in demonstrating the value added by the implementation of this system.

\section{TOWARDS GLOBALIZED ECONOMY: IMPLEMENTATION OF A QUALITY-RISK MANAGEMENT SYSTEM IS THE EASIEST WAY FOR A HEALTHCARE SERVICES PROVIDING UNIT}

Health and labor issues start in healthcare units, from a deficient policy on risk management related healthcare services. Risk management system organization is missing in most of the healthcare units: appointed experts with specific training are missing, employee representatives trained in health and safety at work are missing, and most often, the will and desire of the management to implement such a management system is also missing [9].

Risks related to healthcare services can be of several types: statistical, of conjuncture, unpredictable, incidental, procedural (Figure 1).

In a healthcare service sector organization, not only typology or classification of risk is important, but more than that, the degree of risk manifestation. Medical practice and risk management are closely related. This link is based by the circumstance that the patient- healthcare services provider relationship materialization leads to the immediate establishment of malpractice risk, which, during the provision of medical care, must be considered and managed. 


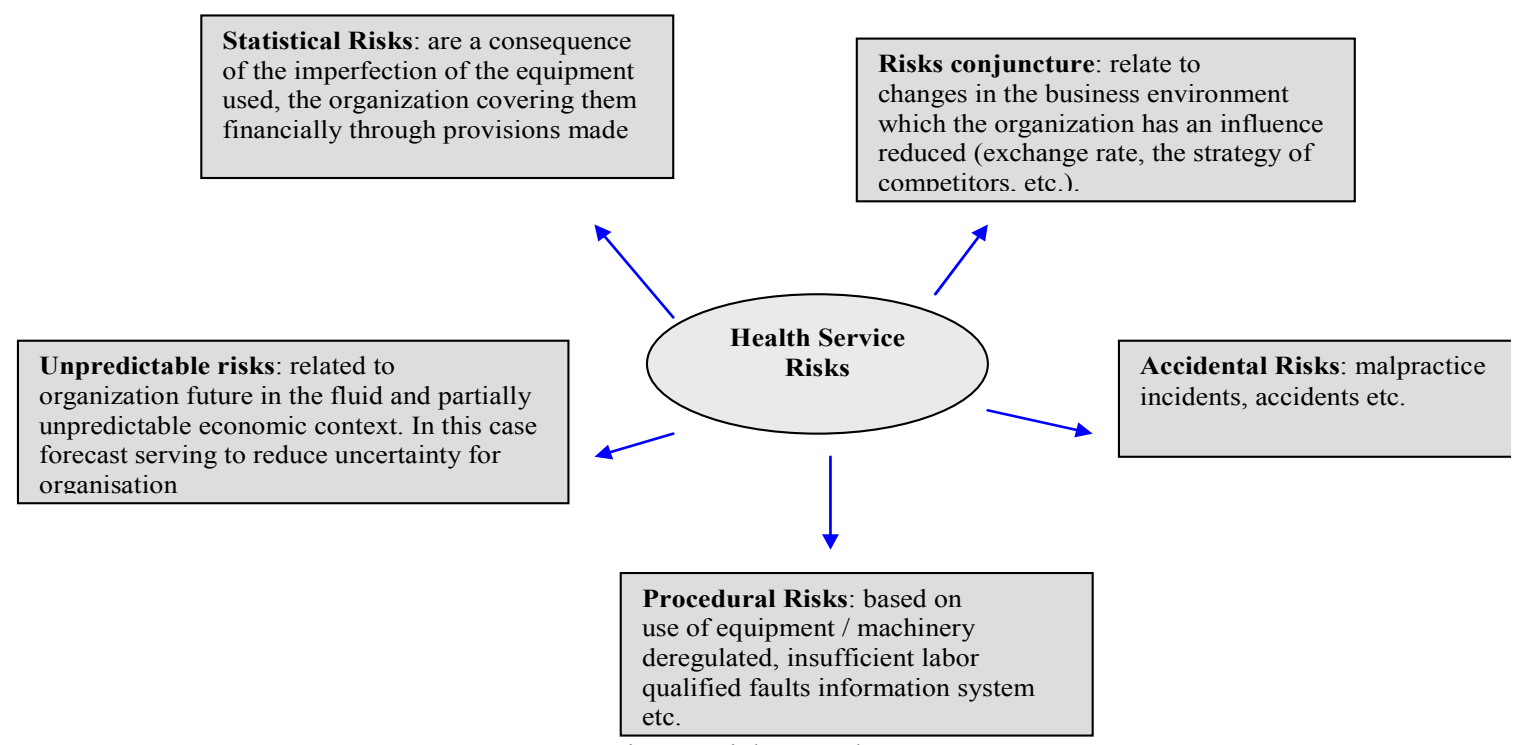

Fig. 1. Risks typology.

The purpose of a risk management program for healthcare is to protect the organization against the risks associated with accidental loss, regardless of cause. One of the foundations of an effective program is the possibility to have a sufficient margin of application to cover all potential sources of risk.

Although many professionals in risk management focus, typically, on occupational risk for healthcare organizations (malpractice), an efficient risk management should take into account a lot of other areas that are equally important for the survival of healthcare services organizations.

A risk management system model for a medical unit plays briefly below. Matrix risks identified risks in a medical unit look like Figure 2.

\begin{tabular}{|c|c|c|c|c|c|c|}
\hline $5=$ Almost certain & \multirow{5}{*}{ 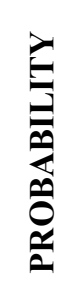 } & 5 & 10 & 15 & 20 & 25 \\
\hline $4=$ Very possible & & 4 & 8 & 12 & 16 & 20 \\
\hline $3=$ Possible & & 3 & 6 & 9 & 12 & 15 \\
\hline $2=$ Unlikely & & 2 & 4 & 6 & 8 & 10 \\
\hline $1=$ Rarely & & 1 & 2 & 3 & 4 & 5 \\
\hline \multirow{2}{*}{\multicolumn{2}{|c|}{$\begin{array}{l}\text { Setting general risk score: } \\
\text { probability } \mathrm{x} \text { impact }\end{array}$}} & \multicolumn{5}{|c|}{ IMPACT } \\
\hline & & 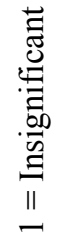 & $\underset{\substack{\| \\
\sim}}{\stackrel{\Xi}{\Xi}}$ & 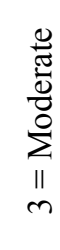 & 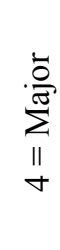 & 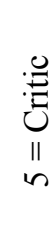 \\
\hline
\end{tabular}

Fig. 2. Risks matrix.

In order to work in risk management system, the organization must identify risks, to evaluate risks, to determine their impact on the organization and determine the level of tolerance (Table 1).

After determining identified risk tolerance level setting organization can a risk register, as shown in Table 2 (brief case study for a small medical unit example). 
Table 1. The level of risks tolerance.

\begin{tabular}{|c|c|c|l|}
\hline Score & Color & Level & \multicolumn{1}{c|}{ Control measures } \\
\hline $\mathbf{1 - 4}$ & & Tolerance & Does not require any control measures \\
\hline $\mathbf{5 - 8}$ & & High tolerance & Requires control measures on medium/long term \\
\hline $\mathbf{9 - 1 2}$ & & Low tolerance & Requires short term controls \\
\hline $\mathbf{1 3 - 2 5}$ & & Intolerance & Requires urgent control measures \\
\hline
\end{tabular}

Table 2. Risk register (selection).

\begin{tabular}{|c|c|c|c|c|c|c|c|}
\hline Compartment & $\begin{array}{c}\text { Risks } \\
\text { typology }\end{array}$ & $\begin{array}{c}\text { Risk } \\
\text { generating } \\
\text { activity } \\
\end{array}$ & Risks description & Probability & Impact & Risk level & $\begin{array}{l}\text { Risks limited } \\
\text { strategy }\end{array}$ \\
\hline 2 & 3 & 4 & 5 & 6 & 7 & $8=6 \times 7$ & 9 \\
\hline $\begin{array}{l}\text { Financial } \\
\text { countable }\end{array}$ & $\begin{array}{l}\text { Unpredictable } \\
\text { risks }\end{array}$ & Procurement & $\begin{array}{l}\text { The acquisitions are } \\
\text { not compliant with } \\
\text { the legislation, are } \\
\text { not advantageous in } \\
\text { terms of financial or } \\
\text { economic }\end{array}$ & 3 & 4 & 12 & $\begin{array}{lr}\text { Reducing } & \text { by } \\
\text { developing } & \text { a } \\
\text { procedure } & \end{array}$ \\
\hline Management & $\begin{array}{l}\text { Risks } \\
\text { conjuncture }\end{array}$ & $\begin{array}{l}\text { Accreditation } \\
\text { process }\end{array}$ & $\begin{array}{l}\text { Risk of non- } \\
\text { compliance with the } \\
\text { legislation in force, } \\
\text { stopping the } \\
\text { institution's activity }\end{array}$ & 3 & 5 & 15 & $\begin{array}{lr}\text { Reducing by } \\
\text { setting up a } \\
\text { monitoring } \\
\text { system } \\
\text { accreditation } \\
\text { process }\end{array}$ \\
\hline Legal & $\begin{array}{l}\text { Risks } \\
\text { conjuncture }\end{array}$ & $\begin{array}{l}\text { Counseling } \\
\text { institution } \\
\text { staff and } \\
\text { management } \\
\text { and issuing } \\
\text { legal opinion }\end{array}$ & $\begin{array}{l}\text { Wrong } \\
\text { interpretation or } \\
\text { application of legal } \\
\text { provision, can cause } \\
\text { damage }\end{array}$ & 2 & 4 & 8 & $\begin{array}{l}\text { Reduction by } \\
\text { issuing an } \\
\text { endorsement } \\
\text { procedures for } \\
\text { legality and } \\
\text { representing the } \\
\text { institution in } \\
\text { court }\end{array}$ \\
\hline $\begin{array}{l}\text { Human } \\
\text { resources }\end{array}$ & $\begin{array}{l}\text { Procedural } \\
\text { risks }\end{array}$ & $\begin{array}{l}\text { The selection } \\
\text { and hiring }\end{array}$ & Hiring inappropriate & 4 & 3 & 12 & $\begin{array}{lr}\text { Reduction } & \text { by } \\
\text { establishing } & \text { an } \\
\text { internal } & \\
\text { procedure } & \text { of } \\
\text { selection and } \\
\text { recruitment }\end{array}$ \\
\hline $\begin{array}{l}\text { Administrativ } \\
\text { e }\end{array}$ & $\begin{array}{l}\text { Accidental } \\
\text { risks }\end{array}$ & $\begin{array}{l}\text { Using } \\
\text { material base } \\
\text { of institution }\end{array}$ & $\begin{array}{l}\text { The material } \\
\text { resources } \\
\text { (buildings, } \\
\text { equipment, } \\
\text { bathroom furniture, } \\
\text { etc.) is not enough } \\
\text { or is not in } \\
\text { accordance with } \\
\text { specific European } \\
\text { standards }\end{array}$ & 4 & 4 & 16 & $\begin{array}{l}\text { Tolerances by } \\
\text { setting a policy } \\
\text { for periodic } \\
\text { evaluation of the } \\
\text { technical state of } \\
\text { the material base } \\
\text { of the institution }\end{array}$ \\
\hline Medical & $\begin{array}{l}\text { Accidental } \\
\text { risks }\end{array}$ & $\begin{array}{l}\text { Provision of } \\
\text { service to the } \\
\text { patient }\end{array}$ & $\begin{array}{l}\text { The services } \\
\text { provided are not } \\
\text { properly highlighted } \\
\text { and reported, and } \\
\text { the expenses and } \\
\text { revenues are not } \\
\text { correct }\end{array}$ & 4 & 4 & 16 & $\begin{array}{l}\text { Partial } \\
\text { acceptance } \\
\text { Develop an } \\
\text { operational } \\
\text { procedures for } \\
\text { activity } \\
\text { highlighting and } \\
\text { reporting and for } \\
\text { pharmacy } \\
\text { management }\end{array}$ \\
\hline
\end{tabular}




\begin{tabular}{|c|c|c|c|c|c|c|c|}
\hline Compartment & $\begin{array}{c}\text { Risks } \\
\text { typology }\end{array}$ & $\begin{array}{c}\text { Risk } \\
\text { generating } \\
\text { activity } \\
\end{array}$ & Risks description & Probability & Impact & Risk level & $\begin{array}{c}\text { Risks limited } \\
\text { strategy }\end{array}$ \\
\hline 2 & 3 & 4 & 5 & 6 & 7 & $8=6 \times 7$ & 9 \\
\hline $\begin{array}{l}\text { Administrativ } \\
\text { e/Medical }\end{array}$ & $\begin{array}{l}\text { Accidental } \\
\text { risks }\end{array}$ & $\begin{array}{l}\text { Provision of } \\
\text { service to the } \\
\text { patient }\end{array}$ & Overcrowding & 5 & 4 & 20 & $\begin{array}{l}\text { Reduction by } \\
\text { creating better } \\
\text { flow stations as } \\
\text { a direct circuit: } \\
\text { admission } \\
\text { diagnosis, } \\
\text { treatment } \\
\text { surgery- } \\
\text { recovery }\end{array}$ \\
\hline Medical & $\begin{array}{l}\text { Accidental } \\
\text { risks }\end{array}$ & $\begin{array}{l}\text { Provision of } \\
\text { service to the } \\
\text { patient }\end{array}$ & $\begin{array}{l}\text { Nosocomial } \\
\text { infections }\end{array}$ & 4 & 5 & 20 & $\begin{array}{l}\text { Reduction } \\
\text { through } \\
\text { continuing } \\
\text { medical } \\
\text { education and } \\
\text { increase the } \\
\text { efficiency of } \\
\text { care (develop } \\
\text { specific } \\
\text { procedure of } \\
\text { care) }\end{array}$ \\
\hline
\end{tabular}

To be truly comprehensive, a risk management program must address the entire scope of the following risk categories:

$>$ Risks of treatment / patient care;

$>$ Risks connected to the medical staff,

$>$ Risks related to other personnel;

$>$ Risks related to the property of the organization;

$>$ Financial Risks;

$>$ Other risks.

On the other hand in order to satisfy the requirements for a specific service, these requirements must be clearly defined by characteristics that can be observed and evaluated by the customer. The requirements concerning processes involved in providing the service should be clearly defined by features of these processes. These features are not always noticeable by the client, but directly affect the quality of service.

When services are provided, differences may occur in the perception of quality between:

- Customer expectations and the perception of the management of the organization;

- The perception of the management of the organization and the specification of the quality of service;

- The specification of the quality of service and the communication with the client;

- The expected service and the service perceived by the client.

If these differences are large, the quality of the service will be strongly affected. It is necessary to diminish and even to eliminate these differences so that customer expectations are fully satisfied by the provided service.

\section{CONCLUSION}

Quality healthcare services are those meeting the real needs of the patient, meaning they are available, accessible, meet the reasonable expectations of the patient and provide for a minimal risk for the patient but also for the grantor of healthcare services [10].

In this respect, the expected results in terms of improved quality of healthcare means the development of quality degree in healthcare services while reducing the risks during healthcare, namely (Table 3).

The implementation of an Integrated Quality Risk Management System in a medical unit will facilitate: 
- Existence of a competitive advantage over other healthcare units, which will make the difference on the market;

- Gaining and maintaining the confidence of patients (maintaining existing patients and attracting new ones);

- Protection and preservation of professionals (maintaining competitiveness, productivity and social cohesion as the medical unit will benefit of true professionals);

- Setting quality objectives is likely to mobilize and focus the energies of the entire staff of the unit;

- Health Security compliance and risk identification, prevention and removal of deviations;

- Cost reduction by three-pronged approach: medical - economic - informational;

- Making arguments based on precise data, data required in the decision-making process, especially towards achieving consistency of the demand and supply of medical services, from identifying patients healthcare needs and to assessing their satisfaction;

- Encouraging the employees to improve their current state by proposals for a better modeling of the working environment (competitiveness, communication, and organization, recognition of effort), of the performed services and process optimization;

- Eliminate ad hoc decisions and uncertainties in the development of procedures and decision-making processes.

Table 3. The expected results of healthcare.

\begin{tabular}{|l|l|}
\hline Equity & Healthcare services for every citizen \\
\hline Accessibility & $\begin{array}{l}\text { Lack of barriers in obtaining medical care. The possibility for the patient to } \\
\text { receive healthcare in the right place, at the right time and according to its needs }\end{array}$ \\
\hline Acceptability & $\begin{array}{l}\text { Healthcare services meet patient expectations. The main components are: } \\
\text { reasonable, clear communication, transparency, promptness, convenience and } \\
\text { professional competence }\end{array}$ \\
\hline Adequacy & $\begin{array}{l}\text { The place where the healthcare process is performed. Providing appropriate } \\
\text { healthcare services with the desired efficacy, with appropriate use of services } \\
\text { required }\end{array}$ \\
\hline Complexity & $\begin{array}{l}\text { The performed healthcare services cover all aspects of disease management, } \\
\text { from prevention to remedy or cure, including psychosocial aspects }\end{array}$ \\
\hline Effectiveness & $\begin{array}{l}\text { The ability of healthcare services organization to achieve the best results in } \\
\text { improving the health of the patient by providing the best healthcare. }\end{array}$ \\
\hline Continuity & $\begin{array}{l}\text { The ability of the organization to get the best results using the best quality of } \\
\text { healthcare provided at the lowest possible cost }\end{array}$ \\
\hline Safety & $\begin{array}{l}\text { The possibility for the patient to receive a complete set of necessary healthcare } \\
\text { services, in a well-established order, without interrupting or repeating diagnosis } \\
\text { procedures. }\end{array}$ \\
\hline Legitimacy & $\begin{array}{l}\text { Minimal risk for the patient, but also for the grantor of healthcare by avoiding or } \\
\text { reducing the potential risk of an intervention or activity, to the patient or staff }\end{array}$ \\
\hline & $\begin{array}{l}\text { Providing healthcare services in accordance with the social principles expressed } \\
\text { by norms, regulations, laws and moral and social values }\end{array}$ \\
\hline
\end{tabular}

Last but not least, implementation of an integrated system will be useful to the top management for a better management of available resources (human, material and financial) and for the development of the manager ability to combine short-term with long-term planning, i.e. a strategy leading to the efficiency of the healthcare service.

\section{REFERENCES}

[1] Militaru, C., Greabu, A., Calitate si standardizare in ingineria mecanica, Ed. Standardizarea, Bucuresti, 2009.

[2] Vladescu, C. (coordinator), Managementul serviciilor de sanatate, Ed. Uranus, Bucuresti, 2000.

[3] * * * OECD Health Statistics 2014 How does Germany compare?, www.oecd.org/els/healthsystems/Briefing-Note-GERMANY-2014.pdf.

[4] Opincaru, C, Galatescu, E.M., Imbri, E., Managementul calitatii serviciilor în unitatile sanitare, Ed. CNI Coresi, București, 2004. 
[5] Sarah, M., The impact of implementing a quality management system within primary care clinics (medical clinics, family medicine cabinet). Results of interest groups structured survey, Universitatea Ludwig-Maximilans din München, 2012.

[6] Sloan, F.A., Mergenhagen, P.M., Burfield, W.B., Bovbjerg, R.R., Hassan, M., Medical malpractice experience of physicians: Predictable or Hazard?, Journal of the American Medical Association (JAMA), 1989, SUA.

[7] Johnson, L.J., Malpractice Dangers in Patient Complaints, 2010, http://www.medscape.com/.

[8] European Agency for Safety and Health at Work, Priorities for occupational safety and health research in Europe for the years 2013-2020, Summary report - (updated Jan 2014), 2014.

[9] Brannan, W. L., Taylor, J.R., A Model for Enterprise Risk Management within a Healthcare Organization, The American Society for Safety Engineer (ASSE), 2010.

[10] Ernst\&Young, Turning risk into results: how leading companies use risk management to fuel better performance, New York, 2012. 